ERRATUM

\title{
Prolactinomas resistant to standard doses of cabergoline: a multicenter study of 92 patients
}

Laurent Vroonen, Marie-Lise Jaffrain-Rea, Patrick Petrossians, Gianluca Tamagno, Philippe Chanson, Lucio Vilar, Françoise Borson-Chazot, Luciana A Naves, Thierry Brue, Blandine Gatta, Brigitte Delemer, Enrica Ciccarelli, Paolo Beck-Peccoz, Philippe Caron, Adrian F Daly and Albert Beckers

\begin{abstract}
The journal apologises for an error in the footnote to table 3 of this article published in the November issue of the European Journal of Endocrinology (vol 167, iss 5, pp 651-662). In the footnote, the information relating to the clinical details of patients should read as:

${ }^{\mathrm{a} C l i n i c a l}$ details on patients 1 and 3 have been reported in references $(40,42)$ respectively.

and not as published

European Journal of Endocrinology 167887
\end{abstract}

\section{References}

40 Petrossians P, de Herder W, Kwekkeboom D, Lamberigts G, Stevenaert A \& Beckers A. Malignant prolactinoma discovered by D2 receptor imaging. Journal of Clinical Endocrinology and Metabolism 200085 398-401. (doi:10.1210/jc.85.1.398)

42 Raverot G, Sturm N, de Fraipont F, Muller M, Salenave S, Caron P, Chabre O, Chanson P, Cortet-Rudelli C, Assaker R, Dufour H, Gaillard S, François P, Jouanneau E, Passagia JG, Bernier M, Cornélius A, Figarella-Branger D, Trouillas J, Borson-Chazot F \& Brue T. Temozolomide treatment in aggressive pituitary tumors and pituitary carcinomas: a French multicenter experience. Journal of Clinical Endocrinology and Metabolism 201095 4592-4599. (doi:10.1210/jc.2010-0644) 